\section{Does Pigment Incorporation into Regular Composite Resins for Posterior Buildups Alter Their Bond Strength?}

\author{
Flaviana Alves $\operatorname{Dias}^{1}\left(\mathbb{0}\right.$, Maria Verônica Rodrigues Conto ${ }^{1}$, (D) Ricardo Danil \\ Guiraldo ${ }^{1}$, Omar Geha ${ }^{1} \mathbb{D}^{\circ}$, Eloisa Aparecida Carlesse Paloco ${ }^{1} \mathbb{B}$, Thais Maria \\ Freire Fernandes ${ }^{2} \mathbb{D}$, Sandrine Bittencourt Berger ${ }^{1}$ (D)
}

\author{
'Department of Restorative Dentistry, \\ Universidade do Norte do Paraná, \\ UNOPAR - Londrina, PR, Brazil \\ ${ }^{2}$ Department of Orthodontics, \\ Universidade do Norte do Paraná, \\ UNOPAR - Londrina, PR, Brazil \\ Correspondence: Dr. Sandrine \\ Bittencourt Berger, Rua Marselha, \\ 183, 86041-100 Londrina, PR, Brasil. \\ Tel: +55-43-3371-9832. e-mail: \\ berger.sandrine@gmail.com
}

\begin{abstract}
Posterior build-ups are auxiliary devices to orthodontic treatment which are made with resin-based or glass ionomer composites. Their removal requires care to protect the tooth surface, therefore, pigmented materials are preferred for a better visualization. This study proposed a pigmentation experimental technique of a regular composite resin, evaluating the microshear bond strength test ( $\mu-\mathrm{SBT})$ of this experimental pigmented resin and comparing with a blue-colored polyacid-modified composite resin, used for posterior buildups. Forty-eight buccal and lingual surfaces of human teeth were used and randomly divided into 4 groups $(n=12)$. The groups were divided into: $C$ (control), regular composite resin; $P$, regular composite resin pigmented; UBL, Ultra Band Lok ${ }^{\mathrm{TM}} ; \mathrm{OB}$, Ortho Bite ${ }^{\mathrm{TM}}$. The composites were bonded using a matrix to obtain microcylinders and prepared for each experimental groups. The samples were then stored in distilled water for $24 \mathrm{~h}$ at $37^{\circ} \mathrm{C}$ followed by a $\mu$-SBT. The types of bond failures were evaluated using a stereoscopic magnifying glass $(10 \times)$. The data were analyzed by ANOVA with Fisher post hoc and Dunnett's test. Means of $\mu-\mathrm{SBT}_{ \pm}$standard deviation (MPa) were: C (39.98a \pm 13.0$), \mathrm{P}(40.09 \mathrm{a} \pm 14.3)$; UBL (33.26ab \pm 8.6$) ; O B(28.70 b \pm 5.5)$. The most prevalent type of failure was adhesive $(80.4 \%)$. Further, was not observed a statistically significant correlation between the bond strength values and failure patterns. The pigmentation of a commercially available resin did not alter the $\mu$-SBT and exhibited similar adhesiveness as a polyacid-modified composite resin.
\end{abstract}

Key Words: build-up material, polyacid modified composite resins, dental materials.

\section{Introduction}

Advances in adhesive technology influence the development of techniques that facilitate orthodontic clinical routines $(1,2)$. Posterior build-ups are an important resource to posterior disocclusion, often used in orthodontics, which allow immediate bonding of orthodontic devices, even in patients with deep overbite (3), assist in dental arch leveling, cause rotation of the occlusal plane, with extrusion of maxillary incisors, intrusion of molars, closure of anterior open bite $(4,5)$, when indicated at the appropriate time $(5,6)$ and they depends just the bitting force of the patient.

Regular composite resins can be used to make the build-ups, but during their removal it is difficult to distinguish the enamel from the resin (7), changing the enamel surface increasing its susceptibility to demineralization and dental caries $(8,9)$. Thus, it is proposed that incorporation of pigments to regular resins may facilitate their removal, making the difference between them and the dental structure, preserving the enamel surface (7). Studies that evaluated and compared the bond strength of resin-based materials with polyacidmodified composite resins are scarce.
The polyacid-modified composite resins, combine the characteristics of two of their components: composite resin and glass ionomer (10). They are sold as a single paste, which is light-cured, with particles of glass load and monomers, such as Bis-GMA and UDMA in the organic matrix, containing about 20 to $50 \%$ of resin (10). The polymerization reaction of the main material is through light activation, with the limited and delayed acid-base reaction, which is typical of ionomeric-based products, after water absorption in the buccal environment (10).

From the above, there is a highlighted need to evaluate enamel adhesion of the materials used for posterior build-ups, since they must withstand the masticatory forces exerted on them during orthodontic treatment, searching for safe and efficient materials which facilitates orthodontic clinical routines. The study goals were to evaluate the influence of experimental pigmentation on the bond strength of regular composite resins and to compare them with different resin-based materials used for posterior build-ups. The tested hypothesis was that pigment incorporation into regular composite resins significantly affects their bond strengths to dental enamel. 


\section{Material and Methods}

\section{Teeth Preparation}

After the application and approval by the Ethics and Research Committee (CAAE 77573417.2.0000.0108), twenty-four extracted caries-free human third molars, extracted for therapeutic reasons, were cleaned with pumice and water and kept immersed in a $0.5 \%$ solution of Chloramine-T for seven days; then stored in distilled water at $4^{\circ} \mathrm{C}$ until their use.

Teeth were decoronated and the crowns were sectioned parallel to their crown longitudinal axis in a mesio-distal direction, using a diamond disc at low-speed (doublesided disc Diamond Flex 0.10 × 22 mm, KG Sorensen, Cotia, SP, Brazil), with the aim of obtaining two surfaces (buccal and lingual) for the experiment $(n=48)$. Then, they were embedded in self-curing acrylic resin (JET, Clássico, Campo Limpo Paulista, SP, Brazil), with the use of $2.0 \mathrm{~cm}$ diameter PVC molds, in such way that buccal and lingual crown surfaces would be parallel to the base. The enamel surfaces were flattened with waterproof silicone-carbide paper (\#400 and \#600) and polished with diamond pastes

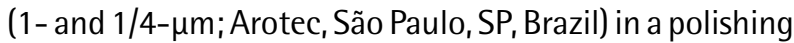
machine (APL4 - Arotec, Cotia, SP, Brazil), under constant water-cooling, and rinsed in an ultrasonic cleaner for total removal of debris.

\section{Experimental Groups}

After specimen preparation, four experimental groups $(n=12)$ were randomly divided as follows: $C$ (control) -
Filtek Z350 ${ }^{\text {TM }} ; \mathrm{P}$ - Filtek Z350 ${ }^{\mathrm{TM}}$ (pigmented); UBL - Ultra Band-Lok Blue ${ }^{\mathrm{Tm}} ; \mathrm{OB}$ - Ortho Bite ${ }^{\mathrm{TM}}$. Nine specimens were determined as the minimum number to enroll in this study, considering 4 groups, mean difference in microshear bond strength $(\mu-\mathrm{SBT})$ between groups of $3.8(\mathrm{SD}=2.2)$ $\mathrm{MPa}, \alpha=0.05$ and test power of 0.8 . The materials used in this study are detailed in Box 1. The choice of these materials was based on the availability of national market and clinical routinely use.

\section{Samples Preparation for $\mu-S B T$}

First, to carry out the adhesive procedures, free enamel surfaces were subjected to etching with $37 \%$ phosphoric acid (Dentsply, Petrópolis, RJ, Brazil) for $30 \mathrm{~s}$, then rinsed, also for $30 \mathrm{~s}$, and air-dried for $5 \mathrm{~s}$, followed by application of the adhesive system Adper ${ }^{\text {TM }}$ Single Bond 2, in groups C, $\mathrm{P}$, with a microbrush and photopolimerized for 20 s. In the groups that received no adhesive system, this step was excluded (groups UBL and OB), according to manufacturer's instructions.

For the group $\mathrm{P}$ (composite resin pigmented), one point $(2.00 \mathrm{~mm})$ of blue permanent ink pen was used (Box 1), in an amount of composite resin that filled a metal matrix (6.0 $\mathrm{mm}$ diameter $\times 0.9 \mathrm{~mm}$ thick), mixed with a flexible spatula suprafill \# 1 (Quinelato, Schobell, Rio Claro, SP, Brazil), on the surface of a glass slab.

Two polyethylene transparent microtubes (Tygon tubing, TYG - 030, Saint Gobain Performance Plastic, Miami Lakes, FL, USA) with an internal diameter of 0.75

Box 1. Materials used in the study: Composition and mode of application

\begin{tabular}{|c|c|c|}
\hline Material & Composition & Application mode \\
\hline $\begin{array}{l}\text { Dental Gel } \\
\text { (Dentsply, Petrópolis, RJ, Brazil) }\end{array}$ & 37\% phosphoric acid & $\begin{array}{l}\text { Acid etching (30s) } \\
\text { Washing (30s) }\end{array}$ \\
\hline $\begin{array}{l}\text { Adper }{ }^{\mathrm{TM}} \text { Single Bond } 2 \\
\text { (3M/ESPE, St. Paul, MN, EUA) }\end{array}$ & $\begin{array}{l}\text { Ethanol, Bis-GMA, filler treated with silane, } \\
\text { HEMA, Glycerol 1,3-dimetacrylate, Copolymer } \\
\text { of itaconic acid, water, UDMA, EDMAB }\end{array}$ & $\begin{array}{l}\text { Air drying(5s) } \\
\text { Curing light (20s) }\end{array}$ \\
\hline $\begin{array}{l}\text { Ultra-Band-Lok }{ }^{\mathrm{TM}} \text { Blue } \\
\text { (Reliance Orthodontic, } \\
\text { Itasca, IL, USA) }\end{array}$ & $\begin{array}{l}\text { Glass Filler, Bis-GMA, TEGDMA, } \\
\text { Monomer } 1 \text { e 2, Amorphous silica }\end{array}$ & Curing light (30s) \\
\hline $\begin{array}{l}\text { Ortho Bite }{ }^{\mathrm{TM}} \text {, Blue } \\
\text { (Dentscare/FGM, } \\
\text { Joinville, SC, Brazil) }\end{array}$ & $\begin{array}{l}\text { Dimethacrylate monomers, methacrylic } \\
\text { monomer phosphate, stabilizers, sodium fluoride, } \\
\text { camphorquinone and coinitiator, Silanized } \\
\text { silicon dioxide inorganic load filler and dye. }\end{array}$ & Curing light (40s) \\
\hline $\begin{array}{l}\text { Filtek Z350 XT }{ }^{\mathrm{TM}} \text { A2B - } \\
\text { Universal Restorative } \\
\text { (3M/ESPE, St. Paul, MN, USA) }\end{array}$ & $\begin{array}{l}\text { Bis-GMA, UDMA, TEGDMA, Bis-EMA, 72.5\% } \\
\text { by weight of inorganic filler loading }\end{array}$ & Curing light (40s) \\
\hline $\begin{array}{l}\text { Radii-cal LED Curing light } \\
\text { (SDI, Baywater, Victoria, Aus) }\end{array}$ & $\begin{array}{l}\text { Blue light in the wavelength range } \\
\text { of } 440-480 \mathrm{~nm} \text { (peak } 460 \mathrm{~nm}) ; \\
\text { Light intensity: } 1200 \mathrm{~mW} / \mathrm{cm} 2 \text { (peak) }\end{array}$ & $\begin{array}{l}\text { Curing times for each material according } \\
\text { to the manufacturers' instruction. }\end{array}$ \\
\hline $\begin{array}{l}\text { Pigmentation Agent: } \\
\text { Permanent ink color blue } \\
\text { (Pilot, Jundiai, SP, Brazil) }\end{array}$ & $\begin{array}{c}2.0 \mathrm{~mm} \text { polyester tipped } \\
\text { Alcohol-based ink, water-resistant. }\end{array}$ & $\begin{array}{l}\text { Resin Pigmentation Filtek } \mathrm{Z} 350^{\mathrm{TM}} \text { : one point } \\
(2.0 \mathrm{~mm}) \text { of the pen in a quantity of resin that } \\
\text { filled a metallic matrix of } 6.0 \mathrm{~mm} \text { x } 0.9 \mathrm{~mm}\end{array}$ \\
\hline
\end{tabular}


$\mathrm{mm}$ and a height of $1.00 \mathrm{~mm}$, were used and filled with the four different resin-based materials, previously selected for the experimental groups and photopolimerized according to the time indicated by each manufacturer (Box 1). After the adhesive procedures were carried out, the samples were stored in distilled water at $37^{\circ} \mathrm{C}$ for 24 $\mathrm{h}$ before the $\mu$-SBT.

\section{$\mu-S B T$}

After the storage period, careful removal of the cylindrical tubes was performed with a \# 11 scalpel blade (Solidor $^{\mathrm{TM}}$, China), resulting in microcylinders which were individually wrapped in a steel wire $(0.2 \mathrm{~mm}$ diameter), fixed to the microshear device, coupled to a universal testing machine (EMIC DL 2000, São José dos Pinhais, $\mathrm{PR}$, Brazil) and tested, with a speed of $0.5 \mathrm{~mm} / \mathrm{min}$, until the failure. The $\mu$-SBT values were transformed into Megapascals (MPa) using the value of the load indicated at the moment of fracture $(\mathrm{N})$, divided by the area of the cylinder inner surface.

\section{Bond Failure Modes}

After calculating the bond strength, the specimens

the bond failure mode, classified as adhesive (interfacial

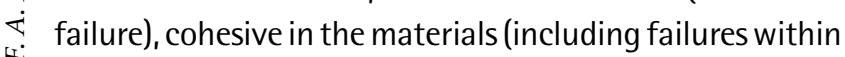
the resin-based materials) and mixed.

\section{Statistical Analysis}

After using Kolmorov-Smirnov normality test, ANOVA was applied to compare the bond strength values intergroup, with Fisher post-hoc. The group $C$ was compared to the other groups by the Dunnett's test. The frequency distribution of failure pattern was compared with Kruskal-Wallis test. The correlation between the bond strength values and the different failure patterns was evaluated with Pearson's correlation test. The significance

Table 1. Microshear bond strength (MPa) of experimental groups ( $\mathrm{n}=12)$

\begin{tabular}{lccc}
\hline \multirow{2}{*}{ Group } & Microshear bond strength (MPa) & \multirow{2}{*}{$\begin{array}{c}\text { Fisher } \\
\text { test§ }\end{array}$} & p value \\
\cline { 2 - 3 } Mean (Standard deviation) & & A & \\
P & $39.98(13.0)$ & A & 0.038 \\
UBL & $40.09(14.3)$ & AB & \\
OB & $33.26(8.6)$ & B & \\
\hline
\end{tabular}

Groups: C, Filtek $350 \mathrm{XT}^{\mathrm{mM}}$ (control); P, Filtek $350 \mathrm{XT}^{\mathrm{TM}}$ pigmented; UBL, Ultra Band-Lok ${ }^{\mathrm{TM}}$ Blue; OB, Ortho Bite ${ }^{\mathrm{TM}}$, blue. §Groups with distinct letters are different statistically by the Fisher test $(\mathrm{p}<0.05)$. * Differ statistically from the control group by the Dunnet test. level used was $5 \%$.

\section{Results}

The mean values and standard deviations of $\mu$-SBT are described in Table 1, showing statistically significant difference between groups $\mathrm{OB}$ and groups $\mathrm{C}$ and $\mathrm{P}$. The most prevalent type of failure was adhesive (80.4\%), with each showed: $\mathrm{C}=72.7 \% ; \mathrm{P}=81.8 \% ; \mathrm{UBL}=83.3 \%$ and $\mathrm{OB}=83.3 \%$ (Table 2). Comparing the failure distribution, Kruskal Wallis analysis (Table 2) showed that there weren't statistical difference between all groups ( $p=0.098)$. No correlation was found between the bond strength value and the different failure patterns $(r=0.195, p=0.193)$.

\section{Discussion}

Analysis and comparison of degree of adhesion of resin-based materials to enamel, can be determined with the use of a $\mu$-SBT, which uses tubes of small dimensions, forwarding control of tested area $(1,11)$. The longevity of posterior build-ups on tooth surfaces depends on the effectiveness of the adhesion to the tooth $(2,12)$ due masticatory loads. The in vitro $\mu$-SBT, performed in this study, are indicated to determine bond strength $(12,13)$ with application of loads on microcylinders adhered to the substrate $(1,14)$.

The small size of the cylinders contributes to a better load distribution, avoiding concentration of forces and premature failures as the cohesive $(1,12,15)$. As reported in the literature, the most of failures resulting from the microshear test are adhesive or mixed, being an advantage related to these tests $(11,16)$. The use of bond failure evaluation shows if the stress concentration is at the adhesive-enamel interface. The high rate of adhesive failures $(80.4 \%)$ confirmed that the interface toothadhesive material was effectively evaluated by the study. The hypothesis that the incorporation of pigments to composite resin decreases bond strength was not supported, as determined by the $\mu$-SBT.

Resins, due to their being biomimetic materials in

Table 2. Frequency distribution (\%) of failure pattern of the groups in the study

\begin{tabular}{lcccc}
\hline \multirow{2}{*}{ Groups } & \multicolumn{3}{c}{ Failure pattern } & p value* \\
\cline { 2 - 4 } & Adhesive & Mixed & Cohesive & \\
\hline C & $8(72.7)$ & $3(27.3)$ & $0(0.0)$ & \\
P & $9(81.8)$ & $2(18.2)$ & $0(0.0)$ & 0.998 \\
UBL & $10(83.3)$ & $2(16.7)$ & $0(0.0)$ & \\
OB & $10(83.3)$ & $2(16.7)$ & $0(0.0)$ & \\
\hline
\end{tabular}

*Kruskal-Wallis test. 
relation to natural teeth, make it difficult to differentiate them from tooth structures at the time of their removal (17). When removing the build-ups it becomes extremely important to define the limits between composite resin and the tooth, preventing iatrogenic damage to the enamel, or permanence of adhesive remnants $(7,8,18)$. Experimental pigmentation was evaluated (group P), with the incorporation of pigment in the composite resin, promoting the differentiation of resin-tooth interface and thus the protection of the tooth structure at the time of build-up removal (7). The composition of the alcohol-based pigment could potentially harm the bond interface, due to the monomers dilution and incomplete polymerization (19), but group P showed no difference in bond strength compared to the control group $\mathrm{C}$, the non-pigmented resin, as determined by the Dunnett's test ( $\mathrm{CxP}: \mathrm{p}=1,000)$.

The adhesion achieved by the experimental pigmented resin exhibited bond strength values close to control and those polyacid-modified composite resins, where the interaction with the ions calcium of tooth occurs with carboxyl functional group of the monomers, with no necessity of adhesive system (Adper ${ }^{\mathrm{TM}}$ Single Bond 2), suggesting similar adhesive behaviors. A minimum bond strength, ranging from 1.5 to $10 \mathrm{MPa}$, has been recommended as suitable for orthodontic purposes (20). All the four experimental groups presented bond strengths higher than the recommended range and only the groups $O B$ had bond strength values which were statistically lower than that of the control group $C_{\text {, as determined by }}$ the Dunnett's test.

The removal of polyethylene transparent microtubes before the $\mu$-SBS tests may cause some cracks along the cylindrical specimens. This situation can interfere with the results of the tests and sometimes cause pretest failures (15). Besides this, the test is capable of detecting a high value of bond strength which increase the sensitivity of the method in evaluating differences among materials (21). These aforementioned aspects of the $\mu$-SBS test may explain the standard deviation showed in this work.

The most prevalence of adhesive failure and the bond strength values of this study may be explained by the low speed used $(0.5 \mathrm{~mm} / \mathrm{min})$ in the $\mu$-SBT test. According to Hara et al. (22), as the cross-head speed increased, the percentages of adhesive failures decreased, which reduced the sensitivity of this test in measuring the true interfacial strength between resin-tooth. When the load is applied to the base of a cylinder at a high speed, the stress deviate from the adhesive interface to other components of the specimen, allowing the cohesive failures $(22,23)$. Further, in the current study, there wasn't a correlation between the bond strength values and failure patterns, probably due to the small amount of paired data.
There may be some possible limitations in this study regarding aging methods. The bond longevity and stability are affected by physical and chemical factors that challenge the adhesive interface over time (24). Occlusal forces and repetitive expansion and contraction stresses induced by temperature changes, and chemical factors were shown to challenge the bond, resulting in various degradation patterns (25). Due to the fact that buildups are only used temporarily, the aging methods, as thermocycling or acid challenge, may not alter significantly the results herein.

It was concluded that pigment incorporation into regular composite resins, did not change the adhesive properties, using the proportions described herein, with the advantage of improvement the material-tooth differentiation, making it easier the composite for posterior build-up has been removed, without the need to purchase an additional product, burdening and increasing the stock, but it requires the additional step of an adhesive system and handling the material pigmentation, unnecessary when using polyacid-modified composite resins. The high rate of the samples adhesive failures confirmed what the study evaluated, effectively, the interface tooth-adhesive material.

\section{Resumo}

Levantes de mordida posterior são dispositivos para o tratamento ortodôntico confeccionados com resinas compostas ou materiais ionoméricos. Cuidado com a remoção destes se faz necessário para proteção da superfície dentária; para tanto, materiais pigmentados são preferidos por proporcionar melhor visualização. Este estudo propõe uma técnica de pigmentação experimental de resinas compostas convencionais, avaliando a resistência ao microcisalhamento ( $\mu$-SBT) na interface de união da resina experimental e superfície de esmalte dental e comparando-a com materiais comercialmente disponiveis para a confecção de levantes de mordida. Quarenta e oito superfícies de dentes humanos foram selecionadas aleatoriamente e divididos em quatro grupos $(n=12)$, de acordo com o material adesivo utilizado: $C$ (Controle, resina composta convencional); $\mathrm{P}$ (pigmentação experimental da resina composta convencional); UBL (Ultra Band Lok ${ }^{\circledR}$ ); OB (Ortho Bite $^{\circledR}$ ). Microcilindros foram preparados para cada tipo de compósito utilizando uma matriz de silicone. As amostras foram mantidas em água destilada por $24 \mathrm{~h}$ a $37^{\circ} \mathrm{C}$, antes da realização do $\mu$-SBT. Os padrões de fratura foram avaliados através de uma lupa estereoscópica com magnificação de 10x. ANOVA com pós teste de Fisher e teste de Dunnett foram utilizados para avaliar os dados. As médias obtidas do $\mu-\mathrm{SBT} \pm$ desvio padrão (MPa) foram: C (39.98a \pm 13.0$), \mathrm{P}(40.09 \mathrm{a} \pm 14.3)$; UBL (33.26ab \pm 8.6$)$; OB $(28.70 b \pm 5.5)$. 0 tipo de fratura mais prevalente foi a adesiva (80.4\%). Além disso, não foi observada correlação estatisticamente significante entre os valores de resistência de união e os padrões de fratura. A técnica de pigmentação experimental não alterou os resultados de $\mu$-SBT da resina composta convencional e mostrou adesividade semelhante à dos compósitos modificados por poliácidos utilizados neste estudo.

\section{Acknowledgements}

This study was financed in part by the Coordenação de Aperfeiçoamento de Pessoal de Nível Superior-Brasil (CAPES) Finance Code 001 - and Conselho Nacional de Desenvolvimento 
Científico e Tecnológico (CNPq).

\section{References}

1. El Zohairy AA, Saber MH, Abdalla AI, Feilzer AJ. Efficacy of microtensile versus microshear bond testing for evaluation of bond strength of dental adhesive systems to enamel. Dent Mater 2010;26:848-854.

2. Evans LS, McGrory KR, English JD, Ontiveros JC, Powers JM, Frey GN, et al. A comparison of shear bond strengths among different self-etching primers. Tex Dent J 2009;126:312-319.

3. Villela HM, Itaborahy W, Pádua ML, Itaborahy R. Aplicabilidade clínica e a importânica dos levantes de mordida na mecânica dos aparelhos autoligados. Rev Clin Ortod Dental Press 2015;14:35-59.

4. Albogha MH, Takahashi I, Sawan MN. Early treatment of anterior open bite: Comparison of the vertical and horizontal morphological changes induced by magnetic bite-blocks and adjusted rapid molar intruders. Korean J Orthod 2015;45:38-46.

5. Vela-Hernandez A, Lopez-Garcia R, Garcia-Sanz V, Paredes-Gallardo V, Lasagabaster-Latorre F. Nonsurgical treatment of skeletal anterior open bite in adult patients: Posterior build-ups. Angle Orthod 2017;87:3340.

6. Janson M. Entrevista. Rev Dental Press Ortodon Ortop Facial 2009;14:33-42.

7. Kaneshima EN, Berger SB, Fernandes TMF, Navarro MFL, Oltramari PVP. Using UV light for adhesive remnant removal after debonding of orthodontic accessories. Braz Oral Res 2018;32:e47.

8. Rossato PH, Kaneshima EN, Domingues F, Fernandes TMF, Berger SB, Oltramari PVP. Do fluorescent agents alter the mechanical strength of orthodontic adhesives? An in vitro and clinical study. Prog Orthod 2020;21:4

9. Taha AA, Hill RG, Fleming PS, Patel MP. Development of a novel bioactive glass for air-abrasion to selectively remove orthodontic adhesives. Clin Oral Investig 2018;22:1839-1849.

10. Nicholson JW. Polyacid-modified composite resins ("compomers") and their use in clinical dentistry. Dent Mater 2007;23:615-622.

11. Armstrong S, Geraldeli S, Maia R, Raposo LH, Soares CJ, Yamagawa J. Adhesion to tooth structure: a critical review of "micro" bond strength test methods. Dent Mater 2010;26:e50-62.

12. Sirisha K, Rambabu T, Ravishankar Y, Ravikumar P. Validity of bond strength tests: A critical review-Part II. J Conserv Dent 2014;17:420426.

13. Weerasinghe DS, Nikaido $T$, Wettasinghe KA, Abayakoon JB, Tagami $J$. Micro-shear bond strength and morphological analysis of a self-etching primer adhesive system to fluorosed enamel. J Dent 2005;33:419-426.

14. Foong J, Lee K, Nguyen C, Tang G, Austin D, Ch'ng Cet al. Comparison of microshear bond strengths of four self-etching bonding systems to enamel using two test methods. Aust Dent J 2006;51:252-257.

15. Andrade AM, Moura SK, Reis A, Loguercio AD, Garcia EJ, Grande RH. Evaluating resin-enamel bonds by microshear and microtensile bond strength tests: effects of composite resin. J Appl Oral Sci 2010;18:591598.

16. Shimada $Y$, Senawongse $P$, Harnirattisai $C$, Burrow MF, Nakaoki $Y$, Tagami J. Bond strength of two adhesive systems to primary and permanent enamel. Oper Dent 2002;27:403-409.

17. Janiszewska-Olszowska J, Szatkiewicz T, Tomkowski R, Tandecka $\mathrm{K}$, Grocholewicz K. Effect of orthodontic debonding and adhesive removal on the enamel - current knowledge and future perspectives - a systematic review. Med Sci Monit 2014;20:1991-2001.

18. Hama T, Namura $Y$, Nishio $Y$, Yoneyama T, Shimizu N. Effect of orthodontic adhesive thickness on force required by debonding pliers. J Oral Sci 2014;56:185-190.

19. Ito S, Hoshino T, lijima M, Tsukamoto N, Pashley DH, Saito T. Water sorption/solubility of self-etching dentin bonding agents. Dent Mater 2010;26:617-626.

20. Naseh $R$, Afshari $M$, Shafiei $F$, Rahnamoon N. Shear bond strength of metal brackets to ceramic surfaces using a universal bonding resin. $J$ Clin Exp Dent 2018;10:e739-e745.

21. Andrade AM, Garcia E, Moura SK, Reis A, Loguercio A, Silva LM, et al. Do the microshear test variables affect the bond strength values? Int J Dent 2012;2012:618960.

22. Hara AT, Pimenta LA, Rodrigues AL, Jr. Influence of cross-head speed on resin-dentin shear bond strength. Dent Mater 2001;17:165-169.

23. Munoz MA, Luque $I$, Hass $V$, Reis $A$, Loguercio $A D$, Bombarda NH. Immediate bonding properties of universal adhesives to dentine. J Dent 2013:41:404-411.

24. Jurubeba JEP, Costa $A R$, Correr-Sobrinho $L$, Tubel $C A M$, Correr $A B$, Vedovello $S A$, et al. Influence of Thermal Cycles Number on Bond Strength of Metallic Brackets to Ceramic. Braz Dent J 2017;28:206-209.

25. Visintini E, Mazzoni A, Vita F, Pasquantonio G, Cadenaro M, Di Lenarda Ret al. Effects of thermocycling and use of ElectroBond on microtensile strength and nanoleakage using commercial one-step self-etch adhesives. Eur J Oral Sci 2008;116:564-570.

Received January 31, 2020 Accepted June 5, 2020 